\title{
History of local taxation in Germany
}

\author{
H. Zimmermann \\ Philipps-Universität Marburg, Marburg, Germany \\ (D) $\underline{0000-0002-9196-0159}$
}

\begin{abstract}
The article discusses the history of local taxation in Germany and its current state, focusing on the correspondence of the existing local taxes to the criteria of optimal local taxation. The author's hypothesis is that the German system of local taxation, which dates back to the imperial period, can and should be reformed in order to meet the internationally recognized criteria. The analysis is based on several criteria: the general criteria, which apply to all taxes, including federal; criteria for local and central taxes and, last but not least, criteria for relationships between local governments. The history of the three local taxes (property tax, business tax and income tax) is viewed in the light of the above-described criteria. It is shown that the local business tax needs to be adjusted according to the criteria of optimal local taxation. The author also explains why, from the theoretical perspective, it was important to transfer the revenue from the income tax to the local level in 1969 and points out that local governments currently lack the authority to set tax rates. The case of the property tax, introduced in 1936, is particularly interesting, taking into consideration the current plans to amend the existing legislation. The author compares the two possible scenarios of the future tax reforms and comes to the conclusion that only one of them fully meets the international standards. The analysis has shown that the local taxation system in Germany is quite efficient, although there is definitely some room for improvement. The combination of the business tax and the income tax allow local authorities to balance the interests of local households and businesses.
\end{abstract}

\section{KEYWORDS}

local tax, tax history, property tax, business tax, local income tax, history of taxation

JEL H24, H25, H71

УДК 336.2:94

Оригинальная статья

\section{История местного налогообложения в Германии}

\author{
Х. Циммерманн \\ Марбургский университет им. Филиппса, Марбург, Германия \\ (D) $\underline{0000-0002-9196-0159}$
}

\begin{abstract}
АННОТАЦИЯ
Не ограничиваясь простым описанием истории местного налогообложения в Германии, автор оценивает существующую систему и ее историческое развитие на соответствие различным критериям оптимального местного налога. Гипотеза автора говорит о том, что немецкая система местного налогообложения, сложившаяся с имперских времен, может быть реформирована, чтобы достаточно хорошо соответствовать общепринятым критериям. Для анализа выделено несколько критериев: критерии для любого налога (также федерального), критерии для местных и центральных налогов и, что не менее важно, критерии для отношений между местными органами власти. Основываясь на этих критериях, описывается история трех местных налогов (налог на имущество, местный налог на бизнес, местный налог на прибыль). Развитие налога
\end{abstract}




\begin{abstract}
на имущество описано с момента его введения в 1936 г. вплоть до настоящего времени. С учетом наличия планов по внесению дальнейших изменений в законодательство, оценены две возможные альтернативы его предстоящего реформирования. Сделан вывод, что из двух предлагаемых вариантов его изменения лишь один соответствует международным стандартам. На основе анализа системы реформ, последовательно изменявших местный промысловый налог, сделан вывод о необходимости его скорейшего реформирования в целях приведения в соответствие с критериями оптимального местного налогообложения. Оправдана, с теоретических позиций, важность передачи на местный уровень власти в 1969 г. доли поступлений от налога на доходы. Вместе с тем отмечен недостаток полномочий местного уровня по установлению налоговой ставки. Анализ показал, что система местного налогообложения в Германии в целом не плоха, но может быть значительно улучшена. Промысловый налог и налог на доходы, работая совместно, создают предпосылки для балансирования интересов коренного населения и предпринимательского сообщества, а в целом три названных источника доходов сформировали неплохую местную систему налогообложения Германии. Вместе с тем все элементы этой системы нуждаются в реформировании.
\end{abstract}

\title{
КЛЮЧЕВЫЕ СЛОВА
}

местный налог, критерии местного налога, местное налогообложение, история налогообложения, налог на имущество, промысловый налог, местный налог на доход

\section{Introduction}

An article on the history of local taxation in Germany can serve several purposes. Whoever works on national tax systems, needs to compare the manner in which various countries have embedded their local taxation in the overall system. Experts specializing on specific local taxes may engage in cross-country comparisons and draw conclusions about the strengths and weaknesses of local taxes in different countries.

The hypothesis that we are going to discuss in this article is that the German local tax system, which evolved in the imperial period, went through a brief democratic phase (1918-1933), then the Nazi period, and, finally, entered the peaceful democratic phase, needs to be adjusted and reformed in order to correspond to modern internationally recognized criteria of effective taxation.

An economist writing on the history of local taxation in Germany looks at the historical development and its results from an economic perspective. The crucial question he or she needs to answer is whether this development moved in the right direction, which means that certain criteria of "optimal" taxation are required. Therefore, in this article, we start with the description of such criteria and an overview of the current system of local taxes in Germany. The following parts deal with the development of individual taxes after World War II, including the major fiscal reforms, and in conclusion we are going to describe the reforms necessary for further development of the system.

\section{Criteria of efficient local taxation and an overview of the current tax system}

\subsection{What is a good local tax?}

Not all taxes can be considered as suitable for use on the local level (for more information on the main criteria see our previous works [1; 2]), for instance, the VAT is not recommended to be introduced as a local tax. The "why", however, is not so easy to pin down, because it contains a multitude of different aspects (see Fisher [3] for an alternative system of tax analysis principles). Boadway and Shah [4] concentrate on decentralizing taxes on the state level. Some economists, for example, Oates [5; 6] and Seiler [7], focus on local taxation. The overview of assessment criteria for local taxes is given in Table 1 below. These criteria can be divided into two groups: those that apply to any tax, local or federal, and those that apply only to local taxation. 
Assessment criteria for local taxes

Table 1

\begin{tabular}{|c|c|c|}
\hline \multirow{2}{*}{$\begin{array}{c}\text { Criteria applied to any } \\
\text { tax within a "rational" tax } \\
\text { system }\end{array}$} & \multicolumn{2}{|c|}{ Criteria applied on lower levels (local taxes) } \\
\hline & Vertical justification framework & $\begin{array}{c}\text { Horizontal justification } \\
\text { framework }\end{array}$ \\
\hline $\begin{array}{l}\text { (1) Fiscal yield and cost } \\
\text { efficiency } \\
\text { (2) Allocational objectives } \\
\text { (3) Objectives of stabilization } \\
\text { and growth } \\
\text { (4) Objectives of social justice }\end{array}$ & $\begin{array}{l}\text { (5) Perceptibility } \\
\text { (6) Changeability } \\
\text { (7) Local economic source of the tax } \\
\text { (8) Balance of interests } \\
\text { (9) Low reaction to business cycles } \\
\text { (10) Proportionate reaction to growth }\end{array}$ & $\begin{array}{l}\text { (11) Avoidance of } \\
\text { unnecessary migration } \\
\text { (12) Inter-local distribution } \\
\text { of the tax base according to } \\
\text { local needs }\end{array}$ \\
\hline
\end{tabular}

Obviously, local taxes should meet some general criteria that apply to all kinds of taxes, for instance, they should provide sufficient revenue net of administrative and taxpayer costs (1). The latter can be an issue when it comes to small local taxes.

All taxes should be collected to meet the allocational objective, which means that private as well as public production should serve the preferences of people and be produced at an optimal cost (2). For local taxes it means that they should be levied under the benefit principle in the sense that they are considered as a remuneration paid for local services by businesses and private households. Moreover, each of these taxes should carry as little excess burden as possible, which means that the income effect should be high and the substitution effect, low. Further we are going to discuss the property tax in more detail and consider the example of the socalled window tax, which illustrates the negative effects of high excess burden. In general, excess burden is associated with a broad tax base, which means that the income tax is better than the consumption tax, the consumption tax is better than the beer tax, and so on.

Local taxes should not interfere more than necessary with the national objectives of dampening business cycles and supporting economic growth (3). If a local tax brings a high revenue in the period of prosperity, this leads to more investment, which increases the "boom" effect. However, if a tax remains stable over the different stages of the business cycle and increases slowly together with the general growth, it provides resources for future development.
Another important aspect to consider is, of course, matters of social justice (4), that is, taxes should take into account people's ability to pay. A good example in this respect is again provided by the property tax, which should follow the above-mentioned benefit principle.

The criteria applied only to local taxes are even more important than general ones. These can be divided into two groups. The first group is defined by the vertical justification framework: what aspects constitute "good" local taxes as opposed to federal and state taxes? The dominant principle for organizing taxation on the local level is the principle of fiscal equivalence by Olson (see $[1 ; 8]$ for more detail). According to this principle, each local government should finance its functions in such a way that the advantages of the additional expenditure are weighed against the disadvantages of the additional tax payment. That is why the principles of perceptibility and changeability are necessary: perceptibility means that a tax must be "felt" (and thus known) in order to be effective (5). The VAT is not "felt", but a personal income tax is. To enable the local government to act this way it is necessary that it can change the tax, especially the tax rate (6) (the principle of changeability). Even though all of this sounds self-evident, we have to admit that German local taxes are lacking in this respect.

Another important aspect is that all local taxes should be generated from the locality's own sources (7), which means that the revenue base is local. This is generally true for fees and charges, but not necessarily true for all local taxes, as it will be shown for the case of the so-called 
German local VAT share. This principle is not so important for the taxpayer, but it is for the local politician, who should be interested in fostering these sources and thereby care for local economic growth and, therefore, for national growth.

The local tax system should have an approximately equal burden on businesses and private households (the principle of balanced interests) (8). It is essential that politicians should pay attention to the interests of both parties rather than concentrate only one of them. Moreover, the tax revenue should not fluctuate together with the business cycle (9), because this makes budget planning difficult and intensifies the business cycle. Instead, the local tax should develop in the way that is somehow proportionate to the growth (10), thus enabling the local budget to finance the growth-relevant infrastructure.

If we look at local taxation within the vertical framework, we can compare local taxes with federal taxes. If we look at them within the horizontal framework, we can compare local taxes in different localities. Economic theory postulates that unnecessary migration is inefficient (see $[1 ; 2])$ and thus should be avoided (11). Therefore, local taxes should not vary significantly between local governments. Finally, the tax base should be distributed between local governments according to the local fiscal needs (12), because otherwise this increases the need for fiscal equalization.

Not all of these criteria can be fulfilled at the same time but when looking at individual local taxes in Germany, we notice significant violations of certain requirements, this may indicate the need for reforms. Since there is no single "good local tax system", there will always be a need for adjustments and reforms within the existing systems.

\subsection{Local taxes in the current system of German local revenue}

For the evaluation of the history of local taxes in Germany it is helpful to first have a look at the existing system, which results from the historical process. Table 2 shows local taxes and fees and charges, which together form revenues from lo- calities' own sources. Their importance was indicated above: local governments are interested in "nursing" this part of local revenue for a number of reasons: a good infrastructure for businesses and private households satisfies the needs of local inhabitants and entrepreneurs and is also an asset when it comes to attracting people and businesses from other regions. A good administration finds out about the needs of the population by, for instance, meeting entrepreneurs and their associations on a regular basis.

The second type of revenues shown in Table 2 is the intergovernmental revenue. Grants are the funds provided by the state government, not "earned" by local effort, but attracted by lobbying elsewhere. It is essential when constructing the system of local revenues to keep the share of the intergovernmental revenue low. Central and state governments have numerous reasons for breaking this rule, but only a few of them seem reasonable while the majority are of a paternalistic nature.

If we go back to the revenue from the locality's own sources, the second rule could be formulated as "fees and charges first". This revenue is based on the benefit principle and has a much closer relation to the payer than the taxpayer has to their tax. When fees and charges are levied, this only occurs for the specific service which has been extended. Therefore, the payer can judge whether the payment is worth the benefit and can judge insofar the efficiency of their local government.

Table 3 illustrates the dynamics of the share of the revenue from the locality's own sources in the period between 1996 and 2016, that is, over the last twenty years. The total sum is now somewhat smaller than it used to be in the beginning, but the share of the locality's own taxes has increased, which is a good sign for local fiscal autonomy. However, the driving force behind this process is the local business tax, whose share increased by five percentage points and which, in its present form, is not considered as a suitable local tax.

It is important to distinguish between the locality's own taxes, which are under 
the jurisdiction of the local government, and tax shares. In international research literature there is often some confusion surrounding what kind of tax sharing is being discussed. If tax sharing occurs in the form of tax revenue sharing, it is of much less value for local fiscal autonomy than tax base sharing (see examples of both cases in Table 2). The German income tax share is based on the local part of the income tax revenue. It is then transferred to the respective local government and thus can be described as a revenue from "own sources". Table 2 includes the data

Table 2

Revenue from the locality's own sources and other revenue types, Mio. EUR, 2016

\begin{tabular}{|c|c|c|c|c|}
\hline & $\begin{array}{c}\text { Local govern- } \\
\text { ments and } \\
\text { districts Mio. } €\end{array}$ & $\%$ & \begin{tabular}{|c|} 
Among: dis- \\
tricts (rayon) \\
Mio. $€$
\end{tabular} & $\%$ \\
\hline A. Revenue from the locality's own sources & 131,327 & 55.3 & 4,282 & 6.0 \\
\hline $\begin{array}{l}\text { 1. Own taxes (right to receive the revenue, partially } \\
\text { also the right to set the tax rate and to administrate) }\end{array}$ & 63,702 & 26.8 & -31 & -0.0 \\
\hline $\begin{array}{l}\text { 1.1. Property tax } \\
\text { including: Property tax } B\end{array}$ & $\begin{array}{l}12,201 \\
11,808\end{array}$ & $\begin{array}{l}5.1 \\
5.0\end{array}$ & & \\
\hline 1.2. Local business tax $(\text { net })^{1)}$ & 38,246 & 16.1 & & \\
\hline $\begin{array}{l}\text { 1.3. "Small" local taxes and revenues similar } \\
\text { to tax }\end{array}$ & 1,447 & 0.6 & & \\
\hline 2. Tax shares (Shared taxes) from the local revenue & 33,432 & 14.1 & & \\
\hline Income tax share & 33,432 & 14.1 & & \\
\hline $\begin{array}{l}\text { 3. Revenue on the basis of the benefit principle (fees } \\
\text { and charges) }\end{array}$ & 34,193 & 14.4 & 4,313 & 6.0 \\
\hline 3.1. Fees & 18,489 & 7.8 & 3,561 & 5.9 \\
\hline 3.2. Contributions & 1,526 & 0.6 & 2 & 0.0 \\
\hline $\begin{array}{l}\text { 3.3. Revenue from market transactions } \\
\text { among: from concessions }\end{array}$ & $\begin{array}{l}8,898 \\
3,212\end{array}$ & $\begin{array}{l}3.8 \\
1.6\end{array}$ & 579 & 0.8 \\
\hline 3.4. Sales revenue (Fixed assets) & 5,280 & 2.2 & 171 & 0.2 \\
\hline $\begin{array}{l}\text { B. Intergovernmental revenue (allocations) (for } \\
\text { the local level as such "from other levels") }\end{array}$ & 108,311 & 45.6 & 64,044 & 89.2 \\
\hline 1. "Grants" out of the value-added tax & 4,393 & 1.9 & - & \\
\hline $\begin{array}{l}\text { 2. Grants (contributions) in the administrative } \\
\text { budget }^{2} \text { ( }\end{array}$ & 88,570 & 40.7 & $62,867^{4)}$ & 87.5 \\
\hline 3. Grants in the asset budget ${ }^{3)}$ & 7,047 & 3.1 & $1,177^{4)}$ & 1.6 \\
\hline C. Net borrowing (- = net repayment) & 1,342 & 0.6 & $-1,470$ & -2.0 \\
\hline D. Other revenues (calculated as difference) & $-3,703$ & -1.6 & 4,953 & 6.9 \\
\hline Total revenue ${ }^{5)}$ & 237,277 & 100.0 & $71,809^{4)}$ & 100.0 \\
\hline $\begin{array}{l}\text { Note: } \\
\text { 1) After deduction of the business tax contribution } \\
\text { 2) Current transfers / payments from local govern } \\
\text { 3) Grants and contributions for investment /. payn } \\
\text { 4) Includes payments from local governments/dis } \\
\text { trative budget, including the district contribution). } \\
\text { 5) Without "special financing transactions" plus n } \\
\text { Source: Statistisches Bundesamt, Fachserie 14: Fin } \\
\text { nisse der Kernhaushalte der Gemeinden und Gemein }\end{array}$ & $\begin{array}{l}\text { nents/districts. } \\
\text { ents from local go } \\
\text { ricts (contains the }\end{array}$ & $\begin{array}{l}\text { jernme } \\
\text { contrib }\end{array}$ & $\begin{array}{l}\text { nts/districts. } \\
\text { utions in the ad }\end{array}$ & Aminis- \\
\hline
\end{tabular}

Dynamics of the revenue from the locality's own sources

\begin{tabular}{|l|r|r|r|r|}
\hline & \multicolumn{1}{|c|}{$\mathbf{1 9 9 6}$} & \multicolumn{1}{|c|}{$\mathbf{2 0 0 3}$} & \multicolumn{1}{|c|}{$\mathbf{2 0 1 3}$} & \multicolumn{1}{c|}{$\mathbf{2 0 1 6}$} \\
\hline Revenue from the locality's own sources & $59.8 \%$ & $61.4 \%$ & $53.2 \%$ & $55.3 \%$ \\
\hline including: own taxes & $20.8 \%$ & $22.8 \%$ & $22.5 \%$ & $26.8 \%$ \\
\hline including: local business tax & $11.5 \%$ & $10.7 \%$ & $16.5 \%$ & $16.1 \%$ \\
\hline
\end{tabular}

Source: Compiled from [1] and its previous editions. 
on "grants" out of the value-added tax, which is the money from the national VAT revenue, from which local governments receive a certain percentage through the application of certain indicators. This transfer occurs without any relation to the local revenue of the VAT, which would be very difficult to calculate.

Up to this point, we have considered local taxes as a single group (see also Ehrlicher [9]), but in the following parts of this paper we are going to look at each of them separately in the historical context (see Table 4). Their history is well described by Heller [10].

\section{The dominance of the local business tax until 1969}

The historical perspective of local taxes in Germany is shown by Table 4 . In this article, we shall assume that the history of local taxation started in Germany in 1955, after the Federal Republic of Germany was formed in 1949. The 1949 Constitution contained explicit provisions for organization of local governments, their functions and revenues, although it should be noted that local governments were considered parts of the states and the Constitution did not specify the three levels of government. Functions of local governments were de- scribed in a general way (Article 28), but a more detailed description was provided for the taxation sphere (Article 106). Over time, the provisions for individual local taxes were further specified in the constitution.

For Table 4 we chose time intervals which, apart from covering the same time span, show the dynamics of local taxation in Germany. In 1959, the income tax share did not exist yet, and neither did the above-mentioned "grants" from the VAT. Therefore, in that period the business tax dominated the local tax system. Let us look at this tax more closely.

The history of the business tax in Germany is quite long [11] (see Hansmeyr [12] for the general description of this tax; for more information about the early tax reform see the Report on the Reform of the Municipal Taxes in the Federal Republic of Germany ${ }^{1}$ ). It was introduced as a central government tax in Prussia in 1810, the same year when commercial freedom was declared and business and crafts were freed from the heavy regulations, some of which went as far back as to the Middle

${ }^{1}$ Wissenschaftlicher Beirat beim Bundesministerium der Finanzen, 1982, Gutachten zur Reform der Gemeindesteuern in der Bundesrepublik Deutschland, Berlin. 153 p.

Dynamics of local taxation in Germany*, Mio. EUR

\begin{tabular}{|c|c|c|c|c|c|c|c|c|}
\hline & \begin{tabular}{|l|}
1955 \\
\end{tabular} & $\%$ & 1975 & $\%$ & 1995 & $\%$ & 2015 & $\%$ \\
\hline $\begin{array}{l}\text { Local business tax (from } 1975 \\
\text { net of transfer) }\end{array}$ & 1,906 & 66.9 & 7,162 & 42.0 & 17,251 & 35.5 & 38,331 & 43.5 \\
\hline among: profit/capital & 1,682 & 59.1 & 5,629 & 33.0 & 17,251 & 35.5 & 38,331 & 43.5 \\
\hline among: payroll & 224 & 7.8 & 1,533 & 9.0 & & & & \\
\hline Income tax share & & & 7,100 & 41.7 & 23,541 & 48.5 & 35,112 & 40.0 \\
\hline Property tax & 704 & 24.7 & 2,122 & 12.4 & 7,027 & 19.4 & 13,215 & 15.0 \\
\hline among: agricultural & 171 & 6.0 & 207 & 1.2 & 314 & 0.6 & 394 & 0.4 \\
\hline among: non-agricultural & 533 & 18.7 & 1,915 & 11.2 & 6,713 & 18.8 & 12,821 & 14.6 \\
\hline $\begin{array}{l}\text { Real estate transfer tax } \\
\text { (-surcharge) }\end{array}$ & 58 & 8.0 & 428 & 2.5 & 151 & 0.3 & & \\
\hline Other local taxes & 177 & 62 & 224 & 1.3 & 578 & 1.2 & 1,439 & 1.6 \\
\hline Local taxes total & 2,845 & 100.0 & 17,036 & 100.0 & 48,548 & 100.0 & 88,097 & 100.0 \\
\hline$\%$ GDP & & 3.1 & & 3.1 & & 2.6 & & 2.9 \\
\hline All German taxes & 21,636 & & 123,767 & & 416,337 & & 673,251 & \\
\hline VAT-transfer ("grants") & & & & & & & 4,690 & \\
\hline
\end{tabular}

* Cash tax revenues.

Source: The author's calculations based on the data provided by the Federal Ministry of Finance, Finanzbericht 2017, p. 301-327. Until 2000: DM converted into Euro by Federal Ministry of Finance. The figures also contain the local taxes of the city-states. 
Ages. Before that, various German states had had smaller charges on business and crafts. When in 1891-1893 a major tax reform was started - the so-called Miquel tax reform - the revenue was assigned to the local level, but the reform of 1920 allowed individual states to decide whether to include the revenue in their own budgets or leave it to local governments. The business tax itself was introduced by the reform of 1936, which also specifically clarified that this was a local tax, that is, it was collected by local authorities without any interference of the state government. The law of 1936 established the three elements of this tax: the tax on profit, the tax on capital and the payroll tax, the latter being left to the discretion of the state government. It should be noted that since the first of these laws were passed in 1810, the tax has not applied to the so-called free professions, such as medical doctors.

In this form the local business tax was a well-designed tax. Together with the property tax it basically covered the three factors of production: labor, capital and land, plus profit as the outcome of managerial capacity. Since then, the quality of the tax has been deteriorating as it has been affected by business lobbies aiming to reduce or abolish it. It is enough to look at the British experience to understand that this would be a short-sighted measure: in 1982, the author of this article took part in a conference, which was held in London between the chambers of commerce of Germany and the UK on the subject of business taxation. When English partners heard of the German local business tax, they sighed: "This is what we need to have our local governments interested in our needs!" Business and especially industry means noise, more traffic and so on and easily loses against the needs of quiet new neighborhoods.

Like in other countries, in Germany there is a problem of taxing businesses with multiple regional activities: for this end, there is a special law regulating this sphere (Zerlegungsgesetz, law of tax segmentation). According to this law, the tax amount is apportioned to respective locations in proportion to the salaries and wages paid. This indicator is easy to calculate, although the success of a specific business and the amount of tax it has to pay does not depend only on the workforce. By the way, this special law is in itself not a tax law, but a law regulating only certain aspects of tax administration.

As was indicated above, the effect of the well-designed business tax was diminished by several "reforms". As it can be seen from Table 4, the payroll tax disappeared. In order to introduce it, local governments needed the permission of the state. As a result, it was not levied in all parts of the country. Maybe this made it easier to abolish it altogether in 1979. This tax had an advantage of providing tax revenues from business, even if the enterprises did not make profit for some time due to the phase of the business cycle or for structural reasons. This, however, also meant that in difficult times the payroll tax produced a specific additional burden, whereas the profit part of the tax was irrelevant for business in difficult times. Thus, the business lobby in this case was successful, and the abolishment of the payroll tax was the first step that made the business tax less effective.

The next step was the abolishment of the capital part of this tax in 1997. Although this part meant an extra burden on businesses in difficult times and thus caused complaints, it had been a useful part of the tax for local governments, because this tax base changes only slowly and it helps them to plan their budgets. As a compensation, local governments received a certain percentage of the national VAT revenue, which means that the revenue was not generated locally (it is practically impossible for the VAT), but was distributed according to some indicators of local economic activity. Together with the abolishment of the payroll tax, the abolishment of the capital part of the business was explained by the fact that all taxes which are not tied to profits are bad for business, because they can create excessive burden when businesses are struggling and there are no profits in sight. However, a more feasible solution would be to look at the complete tax system, 
eliminate all nonprofit elements in other places, but keep them in the local business tax because of the advantages they produce there. Thus, the local business tax is levied on profits ${ }^{2}$ only and its impact can be seen in the development of cities with one large industry. A table in the book "Kommunalfinanzen" shows the business tax revenue of the city of Rüsselsheim, which largely depends on the business tax from Opel car manufacturing ${ }^{3}$. Changes of more than two thirds of the usual tax revenue within one or two years make it extremely difficult for the city manager to plan their budget.

Table 4 shows the dominance of the business tax in local budgets in 1955. More than two thirds of the total local revenue (including the tax revenue) came from the business tax, including the payroll tax. This made local authorities particularly interested in developing business and more prone to allotting land to businesses rather than using it for residential purposes. In the years of reconstruction, which laid the foundation for further economic growth, it was probably a feasible solution. However, with time the need to retain qualified workforce became more urgent for businesses, and it became more important to provide amenities for upper-level personnel. An early study on regional preferences of the population [13] showed that the upward-striving families wanted to live on the border of an agglomeration and have access to good infrastructure for families, which meant that in 1969 the local government's attention shifted from "only business" to include the interests of private households as well ${ }^{4}$.

2 The calculation of profit as the tax base is rather complicated. The typical profit as the result of bookkeeping is adjust-ed by various inclusions and deductions, for instance, to maintain financing neutrality between equity financing and debt financing.

${ }^{3}$ Zimmermann/Döring 2019 [1], chapter 4, figure 4.3 .

${ }^{4}$ The decisive influence came from the government report (Troeger-Kommission (Kommission für die Finanzreform), 1966, Gutachten über die Finanzreform in der Bundesrepublik Deutschland, Stuttgart. 275 p.).

\section{The decisive reform of 1969: introducing the income tax share}

Before 1969, there had been no local tax on personal or local income generation, only small taxes on consumption. Furthermore, the German system of local taxes followed the "one tax, one budget" principle. This principle became particularly evident for the author of this article, when he started his work in Russia in 2000 on the subject of intergovernmental relations. It was in the volume of the first World Bank mission of 1992 [14] that he had influenced the change from $100 \%$ of this rule to the introduction of a major element of tax sharing within the income tax, keeping in mind the experience of 1969 and the debates of that period. Sharing a major tax between different levels of government, in the case of Germany between all levels, alleviates the burden of a major reduction in tax revenue by distributing this loss among the levels. At the same time the tax law applies equally across the country (unlike the USA), which makes it easier for businesses to diversify into other states or communities. The problem is that only the central government is usually authorized to change the tax rate. It is true that the reform of 1969 provided the government with an opportunity to introduce a local tax rate variation by adopting a simple federal law, without having to amend the constitution again. The government, however, did not use this opportunity for reasons of political economy and the situation has not changed since then. The fiscally weaker German states are afraid that this could lead to a race to the bottom for these local tax rates. Germany is a country longing for unified rules and is therefore opposed to regional competition in any field.

Local governments were to receive much more revenue - more than the vertical distribution of functions would justify through the income tax share. Therefore, local governments had to hand a part of their business tax revenue to the state and federal government. Table 1 thus shows only the net amount left after deducting the contribution to the upper levels.

The introduction of the income tax share was good for local finances and 
decision-making, but it has a flaw of not giving local governments (and state governments, too) the right to set their own tax rates (see Table 4 for the results of the reform). In 1975, the share of the business tax was reduced from $67 \%$ in 1955 to $42 \%$ in 1975 , and the new income tax share also contributed $42 \%$. At that point, the above-mentioned balance of interests between business and private households was perfect, which meant that in agglomeration areas, central cities went on profiting from the business tax but at the same time suburban communities received their share of the income tax from their inhabitants. Thus, the conflict of interests had been reduced considerably. In comparison with Russia, it should be noted that the income tax revenue is transferred directly to the home town of the taxpayer and is not distributed by place of work. This is irrespective of whether he or she earns money outside or inside the agglomeration center. At least, this was the case when the author worked in Russia and then in Ukraine from 2000 to 2016, when this was a major issue in these countries. Central cities, of course, wanted to keep their income tax revenues from commuters, because it had been earned there and had been paid to the treasury at the place of work as it usually happens, also in Germany. Statistical reasons referring to the difficulty of splitting this revenue were not very convincing and may have been overcome in the meantime.

Compared to other existing or possible local taxes, the income tax has a number of advantages when seen from the economic perspective. As a very broad tax, it carries very little excess burden, because if one wanted to evade it, it would mean giving up one's income, which people usually avoid doing. Moreover, the tax rules are the same all over the country, which makes it easier for people to move between communities. Last not least, the costs of tax administration and taxpayer are very low, because the tax is levied as the national tax anyway.

The tax then only needs to be split between the levels and on each level between individual entities, which requires some specific decisions. Similar to the case of the local business tax, the tax amount has to be assigned separately to individual commercial entities, if a business has several locations. For Germany this is done by the above-mentioned law Zerlegungsgesetz. The national amount of the income tax revenue goes to the federal and state governments at $42.5 \%$ each, and this occurs by regional origin. Therefore, the states remain interested in improving "their" tax base. The local governments are guaranteed the remaining $15 \%$ of the sum inside the state. The amount should be allocated basically by regional origin to each community. However, a cap is introduced, because otherwise, as a colleague of mine said smilingly, one tennis player would finance a whole small community, by which he meant Boris Becker. Therefore, the amount to which a taxpayer's $15 \%$-share should go to the local budget is capped, that is, their tax is included as if they earned only the reduced amount. This procedure does not use up the money in the total amount for local governments inside a state but because this left-over money belongs to local governments, it is used to fill up this amount again. The system is even more complicated than this (see $[1 ; 2]$ for more detail). The system is quite complicated, but we believe that it makes the right emphasis on regional origin.

As it was mentioned before, the reform of 1969 permitted to introduce the tax rate policy by local government without amending the constitution again but this permission unfortunately has not been used until today. There is no technical reason which would forbid a local tax rate policy within a system of shared income tax, as it was shown a long time ago [15], so this question still remains on the agenda for further reforms.

\section{A reliable source: the property tax}

Looking again at Table 4 , we can see that the system of local taxes was more or less adequate in 1975, as businesses and private households paid similar amounts to the local budget. However, the property tax accounted for a rather small share of this sum, compared to 
other developed countries. In Germany, this tax is actually a real estate tax, whereas property taxes, such as the ones found in the USA, may also apply to property other than real estate.

The property tax is possibly the oldest local tax [16]: the less elaborate predecessor of this tax was the so-called "window tax". In the beginning, having doors and windows in houses served as an indicator of wealth and thus their owners were subject to special taxes. This resulted in a situation when people built strange houses without windows and with very small doors, which means that the tax burden was really high [17]. In Germany, Prussia used such tax since the above-mentioned Miquel reform of 1892, and the law of 1936 introduced this tax in its present form (see [18] and [19]). The values were calculated in an almost perfectionist way. The consequence was that instead of the intended five-year interval the next - incomplete re-assessment occurred in 1964 and never again after that. In eastern German states even the assessment of 1964 was not carried out. The result was that the value of the property underwent different changes, from booming central cities to poor peripheral towns. After several admonishments, the constitutional court ruled in March 2018 that in this form the law was unconstitutional and had to be remedied within a few years, which provoked a discussion as to which model should be chosen.

Nobody wanted to return to the old sophisticated model. Instead, the discussion concentrated on the choice between rather simple models, which mainly rely on the land surface, and their opposite models with full market assessment, similar to the ones used in the USA. A good foundation for this reform could have become a well-developed model which was introduced for consideration at the Upper House of the German Parliament (Bundesrat) in 2016, but this project was not pursued further due to the upcoming national elections (for more detail on reform options see Scheffler and Roith [20]).

The other two options of the reform which were considered further were to introduce an extremely simple tax on land area only, without value indication, or to use a rather broad-based tax, but with a complicated element. On February 1, 2019, the Federal Ministry of Finance and the states agreed on the version that uses land value and for buildings the age and the average regional rent ${ }^{5}$ [23]. This model corresponds to internationally recognized criteria and is going to provide a foundation for the draft law, which is now being developed and shall hopefully be introduced. Therefore, February 1, 2019, shall be remembered as an important date in the history of German local taxation. Moreover, this decision has become a disappointment for those who were hoping for an "abolishment through non-action", as it happened with the national wealth tax in 1996.

However, the discussion about the reform may be reopened due to the possible regionalization of the property tax [21], which happened quite late in the process. In this case the right to issue a law would be transferred from the federal government to the states, whereas the right to set tax rates and to receive the revenue would remain with local governments. It is likely that one state (Bavaria) will then choose the tax on land area without valuation, whereas others will choose the more demanding model. This phenomenon would be new for the Federal Republic of Germany, and so far it has received mixed reactions from experts in this field.

As a rule, one would prefer a nationwide law for such an important local tax, so that the right to set the tax rate would remain on the local level. Regionalization would be disastrous for the local business tax, because an enterprise with subsidiaries in several states would be forced to adjust its method of calculating profit for each of the states. The situation is different for the property tax. If an enterprise has property in various states, it would receive respective tax bills as before, but with different sums to pay, which means

${ }^{5}$ Federal Ministry of Finance, (2019), Bund und Länder verständigen sich auf Eckpunkte für Grundsteuer-Reform. Berlin, February 1, 2019. Available at: https://www.bundesfinanzministerium.de/Content/DE/Video/2019/201902-01-eckpunkte-grundsteuer-reform / 201902-01-eckpunkte-grundsteuer-reform.html 
that there would be no need for special calculations.

Looking at the demand for more decentralization the result would be positive, though it would not be local fiscal economy which would be strengthened, but the economy of the states. Over time, it is likely that the better solution for the property tax will prevail. However, the varying preferences within a large state such as Bavaria would not be considered, for instance, between the rich capital and poorer peripheral regions.

It is also interesting to consider the tax effects of this new element of regionalization. As W. Richter said in a personal conversation with the author of this article, "an investor would find it attractive to invest preferably in rather expensive Bavarian residential locations. Because of the mere area base of the tax there is no need to consider market driven tax hikes. This is interesting for profit-oriented investors. Investors also would not need to be afraid that local politics might ruin their calculations. With the concern for the neglected residential locations the tax rates would not be easy to raise. One would especially expect therefore a boom in real estate prices in expensive Bavarian residential locations". Comparable good locations in states with a value-based property tax would thus lose some part of their attractiveness.

The currently existing system consists of two parts (see Table 3): agricultural and non-agricultural. The first part deals with agricultural property as it is very important for agriculturally dominated local governments. It is also permitted to tax this property much lower in order to subsidize agriculture. The second part is called nonagricultural because it deals with property of private households, businesses and so on. The forthcoming reform is expected to overcome this distinction between agricultural and non-agricultural property.

The question as to whether public property, property of churches and so on should be included is still open, but we are not going to discuss it here. The argument that in the case of public property the money would go from one public budget to another public budget does not make much sense since these budgets belong to different levels of government. If we look at the case of Marburg, a city with a large university, the question arises as to why the local government should provide property without any remuneration, if the scarce land could be used to attract tax paying units. In addressing this issue, Germany can benefit from the experience of other countries, for example, Canada, where payments in lieu of taxes perform the function of transfers between the levels.

Table 4 shows that after 1955 the property tax contributed a share of somewhat below $20 \%$ to the local tax revenue, which is not much compared with other countries and, taking into consideration its strengths as a local tax, might well be higher.

\section{Fiddling with small taxes}

All local governments across the world are always tempted to levy additional small taxes for this and that purpose, hoping to reap additional revenue. Some of the taxes may be useful, like dog taxes, which prevent people from keeping too many dogs. In Germany, a few years ago, several states introduced a tax on second homes. Such tax may be useful in resort communities, where people buy second homes and then leave them empty for most of the year, which does not look good and results in land scarcity. Many cities now also levy a city tax for hotel stays, which is basically a kind of tourist entry fee. Recently in Hessia some communities have introduced horse taxes on leisure horses, arguing that this way highincome persons could contribute more to the prosperity of the place.

Many such small local taxes are actually "nuisance taxes" [14, p. 183], that is, they yield an insignificant revenue while being at the same time burdensome for taxpayers and authorities, in a word, are counterproductive. Table 5 shows taxes of this type in Germany. According to the data in Table 3, they account together for less than $2 \%$ of the local tax revenue. These taxes are introduced by passing a law on the local level, whereas all the other taxes discussed above are based on 
federal laws, although they do provide local governments with a source of revenue.

Table 5

"Small" local taxes, Mio EUR, 2016

\begin{tabular}{|l|r|r|}
\hline “Small” local taxes & $\mathbf{1 , 3 9 1 . 3}$ & $\mathbf{9 6 . 2} \%$ \\
\hline Entertainment tax & 898.9 & $22.0 \%$ \\
\hline Dog license fee & 318.4 & $22.0 \%$ \\
\hline Second home tax & 129.3 & $8.9 \%$ \\
\hline Hunting- and fishing tax & 9.6 & $0.7 \%$ \\
\hline Other taxes & 35.1 & $2.4 \%$ \\
\hline Tax-like levies ${ }^{1)}$ & 55.5 & $3.8 \%$ \\
\hline Casino levy & 22.5 & $1.6 \%$ \\
\hline Tourism duty & 21.6 & $1.5 \%$ \\
\hline Other levies & 11.4 & $0.8 \%$ \\
\hline Total revenue & $\mathbf{1 , 4 4 6 . 8}$ & $\mathbf{1 0 0 . 0 \%}$ \\
\hline $\begin{array}{l}\text { For information only: } \\
\text { Concessionary duty } \\
\text { (as a part of the market } \\
\text { transactions revenue) }\end{array}$ & & \\
\hline Utilities & $3,180.5$ & \\
\hline $\begin{array}{l}\text { including: electricity } \\
\text { supply }\end{array}$ & $1,978.5$ & \\
\hline Traffic companies & 5.2 & \\
\hline Economy and tourism & 26.1 & \\
\hline Concessionary duty total & $3,211.8$ & \\
\hline
\end{tabular}

Source: Statistisches Bundesamt, Fachserie 14, Reihe 3.3, Rechnungsergebnisse der Kernhaushalte der Gemeinden und Gemeindeverbände 2016, Wiesbaden 2018, Table 1.10. - Concessionary duty: direct information from Statistisches Bundesamt.

An additional revenue source, which possibly does not exist in many countries, are concessionary payments from, for instance, electricity producing companies to local governments for the permission to have their power lines go through the local government area. The revenue from these concessionary payments is more than three times the amount of the revenue obtained from all small local taxes.

\section{Looking ahead: necessary reforms}

Looking at the development of local taxation in Germany since 1949, one can conclude that initially it developed in the right direction, as it is illustrated by the data for 1975 in Table 3. In 1975, businesses and private households were taxed equally; the property tax was in place and unchallenged by the court; and the strange "share" of the VAT had not yet been introduced. We believe that this is the optimal structure that the German taxation system should go back to.

The hardest task in this respect is to deal with the local business tax as the necessary reform had time and again been impeded by the objections of businesses. On the other hand, even if the reform is not introduced, it is still better for the country to live with this "bad" form of a local business tax than without it, as the case of Great Britain had shown.

As for the income tax share, it appears fine in its setup, although, since 1969, local governments has been lacking the authority to set tax rates.

A reform of the property tax is under way, and hopefully it will move in the right direction. In general, the German local tax system is quite productive and, with some improvements, holds significant potential for further development

\section{References}

1. Zimmermann H., Döring T. Kommunalfinanzen. $4^{\text {th }}$ ed. Berlin; 2019.

2. Zimmermann H. Munitsipalnye Financy. Moscow; 2003.

3. Fisher R. C. State and local public finance. $4^{\text {th }}$ ed. Chicago; 2016.

4. Boadway R., Shah A. Fiscal federalism. Cambridge et al.; 2009..

5. Oates W. E. Fiscal Federalism. New York: Harcourt Brace Jovanovich; 1972.

6. Oates W. E. The Economics of Fiscal Federalism and Local Finance. Cheltenham: Edward Elgar; 1998.

7. Seiler G. Gemeinden III: Finanzen. In: Handwörterbuch der Wirtschaftswissenschaft, Vol. 3, Gustav Fischer, J. C. B. Mohr, Vandenhoeck \& Ruprecht, Stuttgart. New York: Tübingen, Göttingen, Zürich; 1981, pp. 507-525.

8. Olson M. The Principle of Fiscal Equivalence: The Division of Responsibilities among Different Levels of Government. American Economic Review. 1969;59(2):479-487.

9. Ehrlicher W. Finanzwirtschaft, öffentliche II: Die Finanzen der Bundesrepublik Deutschland. In: Handwörterbuch der Wirtschaftswissenschaft, Vol. 3, Gustav Fischer, J. C. B. Mohr, Vandenhoeck \& Ruprecht, Stuttgart. New York: Tübingen, Göttingen, Zürich; 1981, pp. 164-195.

10. Heller S. Die Geschichte der Grundsteuer. In: Potsdamer Kommunalrechtstage. Potsdam: Kommunalwissenschaftliches Institut; University of Potsdam; 2018, pp. 145-162. 
11. Littmann K. Gewerbesteuern. In: Handbuch der Finanzwissenschaft. $3^{\text {rd }}$ ed. Vol. 2. Tübingen; 1980, pp. 607-632.

12. Hansmeyer K.-H. Gewerbesteuer. In: Handwörterbuch der Wirtschaftswissenschaft. Vol. 3, Gustav Fischer, J. C. B. Mohr, Vandenhoeck \& Ruprecht, Stuttgart. New York: Tübingen, Göttingen, Zürich; 1981, pp. 617-633.

13. Zimmermann H., Anderseck K., Reding, K., Zimmermann A. Regionale Präferenzen. Publication Series Gesellschaft für Regionale Strukturentwicklung, Vol. 2. Bonn; 1973.

14. Wallich C. Fiscal decentralization - Intergovernmental relations in Russia. The World Bank, Studies of Economies in Transition, Vol. 6. Washington, D.C.; 1992.

15. Hansmeyer K.-H., Zimmermann H. Möglichkeiten der Einführung eines Hebesatzrechts beim gemeindlichen Einkommensteueranteil. In: Archiv für Kommunalwissenschaften, 32 Year. 1993, pp. 221-244.

16. Andreae C.-A. Grundsteuern. In: Handbuch der Finanzwissenschaft. $3^{\text {rd }}$ ed., Vol. 2. Tübingen; 1980, pp. 576-606.

17. Oates W. E., Schwab R. M. The window tax: A case study in excess burden. Journal of Economic Perspectives. 2015;29(1):163-180. DOI: 10.1257/jep.29.1.163

18. Zimmermann H. Grundsteuer. In: Staatslexikon. $8^{\text {th }}$ ed. Vol. 2. Freiburg-Basel-Wien; 2018, pp. 1486-1487.

19. Hansmeyer K.-H. Grundsteuer. In: Handwörterbuch der Wirtschaftswissenschaft. Vol. 3, Gustav Fischer, J. C. B. Mohr, Vandenhoeck \& Ruprecht, Stuttgart. New York: Tübingen, Göttingen, Zürich; 1981, pp. 726-743.

20. Scheffler W., Roith M. Leitlinien für eine Reform der Grundsteuer, ifst, Vol. 526. Berlin; 2018.

21. Schäfers M. Scholzsche Grundsteuer wackelt. In: Frankfurter Allgemeine Zeitung. 2019, p. 20.

\section{Acknowledgements}

The author is grateful to the unknown referee for helpful suggestions.

\section{Authors}

Horst Zimmermann - PhD in Public Finance, Professor Emeritus for Public Finance, Philipps University of Marburg, a member of the Scientific Advisory Board to the Federal Ministry of Finance (Koenigsberger Str. 17, D-35043 Marburg, Germany); (ID) 0000-0002-9196-0159; ResearcherID: E-5286-2018; ScopusID: 7402792821; e-mail: horstzimmermann1@freenet.de

\section{For citation}

Zimmermann H. History of local taxation in Germany. Journal of Tax Reform. 2019;5(1):57-69. DOI: $10.15826 /$ jtr.2019.5.1.060

\section{Article info}

Received December 17, 2018; accepted March 12, 2019

\section{Информация об авторе}

Циммерманн Хорст - доктор экономических наук, почетный профессор Марбургского университета им. Филиппса, член научно-консультативного совета при Министерстве финансов ФРГ (Германия, 35043, Марбург, Кёнигсбергерштрассе, 17); (D 0000-0002-9196-0159; ResearcherID: E-5286-2018; ScopusID: 7402792821; e-mail: horstzimmermann1@freenet.de

\section{Благодарности}

Автор благодарен неизвестному рецензенту за полезные советы.

\section{Аля цитирования}

Циммерманн X. История местного налогообложения в Германии // Journal of Tax Reform. 2019. T. 5, № 1. C. 57-69. DOI: 10.15826/jtr.2019.5.1.060

\section{Информация о статье}

Дата поступления 17 декабря 2018 г.; дата принятия к печати 12 марта 2019 г. 